\title{
Protection of channel catfish Ictalurus punctatus following natural exposure to Edwardsiella ictaluri and effects of feeding antigen on antibody titer*
}

\author{
Somsak Vinitnantharat, John A. Plumb \\ Department of Fisheries and Allied Aquacultures, Alabama Agricultural Experiment Station, Auburn University, \\ Auburn, Alabama 36849, USA
}

\begin{abstract}
Channel catfish Ictalurus punctatus that survived a natural infection of Edwardsiella ictaluri demonstrated a strong relationship between $E$. ictaluri agglutination antibody titer and degree of protection upon challenge. Intraperitoneal injection of $2.0 \times 10^{7}$ cells fish ${ }^{-1}$ killed $100 \%$ of fish with antibody titers of 0 and 128 (low); $77.8 \%$ of fish with titers from 256 to 512 (medium); and $57.7 \%$ of the fish with titers of $>1024$ (high). A second challenge trial, using $5.1 \times 10^{5}$ cells fish $^{-1}$, produced $72.2 \%$ mortality in fish with no detectable antibody titers, $51.3 \%$ in low antibody titer fish, $25.0 \%$ in medium antibody titer fish, and $6.5 \%$ in high antibody titer fish. These results demonstrate that channel catfish have protective antibodies after they are exposed to E. ictaluri but that a titer of over 256 is necessary to ensure detectable protection against an injected challenge. If fish are challenged with large numbers of pathogen this protective immunity can be overcome. Administration of E. ictaluri cell extract impregnated feed every 5 or $10 \mathrm{~d}$ to fish vaccinated by injection resulted in the fish maintaining their antibody titer, whereas the antibody titers of fish receiving no oral vaccine continued to decline.
\end{abstract}

\section{INTRODUCTION}

Enteric septicemia of catfish (ESC) is the most serious infectious disease of the catfish industry in the United States. The causative agent of ESC is Edwardsiella ictaluri (Hawke et al. 1981) and during the past decade, this organism has caused millions of dollars in losses among cultured channel catfish Ictalurus punctatus. It has been shown that channel catfish which either survive an ESC epizootic, or are vaccinated with an $E$. ictaluri bacterin, produce agglutinating humoral antibodies (Plumb et al. 1986, Vinitnantharat \& Plumb 1992). The significance of these antibodies is unclear, but Saeed \& Plumb (1986) indicated that humoral antibody titers to $E$. ictaluri lipopolysaccharide (LPS) must exceed 1:500 before the fish are protected against challenge with live E. ictaluri. Furthermore, it has been reported that high agglutinating antibody titers against the LPS of Aeromonas salmonicida did not correlate with protection against furunculosis (Michel \& Faivre

\footnotetext{
- Research supported by Southern Regional Aquaculture Committee SRAC-PINST, CFISH-2, and U.S. Fish and Wildlife Service Contract No. 1416000-9155015A
}

1982), and Cossarini-Dunier (1986) was unable to show a correlation between serum antibody and protection in trout vaccinated against enteric redmouth disease (Yersinia ruckeri).

The objective of this study was to determine the humoral antibody level to Edwardsiella ictaluri in channel catfish after an epizootic of ESC and to determine if their immunity to reinfection was related to antibody titers. A second objective was to determine if feeding a diet containing cell extracts of E. ictaluri (oral vaccine) cells to injection-vaccinated fish would maintain a humoral antibody titer.

\section{METHODS}

Channel catfish (average weight $19.1 \mathrm{~g}$ ) that had survived a natural Edwardsiella ictaluri infection were bled to determine agglutinating antibody titer against E. ictaluri. Individual fish were marked by a fin-clip so they could be identified later and the agglutination antibody titer of individual fish was determined by the method of Sandick \& Rose (1980). The fish were divided into 4 groups based upon their antibody titer 
Table 1. Number of channel catfish Ictalurus punctatus with agglutinating antibody to Edwardsiella ictaluri following natural exposure to the bacterium

\begin{tabular}{|c|c|c|c|}
\hline \multirow[t]{2}{*}{ Classification } & \multirow{2}{*}{$\begin{array}{l}\text { Antibody } \\
\text { titer }^{\circ}\end{array}$} & \multicolumn{2}{|c|}{ Number of fish } \\
\hline & & Trial 1 & Trial 2 \\
\hline Negative & 0 & 10 & 18 \\
\hline Low & 128 & 18 & 49 \\
\hline Medium & $256-512$ & 18 & 20 \\
\hline High & $>1024$ & 26 & 31 \\
\hline \multicolumn{2}{|l|}{ Total } & 72 & 118 \\
\hline \multicolumn{4}{|c|}{$\begin{array}{l}\text { " Titer was the highest dilution of serum that produced } \\
\text { agglutination of E. ictaluri (Sandick \& Rose 1980) }\end{array}$} \\
\hline
\end{tabular}

(reciprocal of the greatest dilution of serum producing agglutination): negative (0 titer), low titer $(<128)$, medium titer (256 and 512), and high titer (>1024) (Table 1). Each group was challenged by intraperitoneal injection with $2.0 \times 10^{7}$ cells fish $^{-1}$ of virulent E. ictaluri (ALG-88-122 isolated from the kidney of a moribund channel catfish, Greensboro, Alabama, 1988) and stocked into a 100 l aerated trough with a flow rate of $1 \mathrm{l} \mathrm{min}^{-1}$ of fresh water $\left(25 \pm 1^{\circ} \mathrm{C}\right)$. Mortality was recorded for a period of $14 \mathrm{~d}$ and dead fish were necropsied for the presence of E. ictaluri in the kidney. In a second trial, performed $2 \mathrm{wk}$ after the first but in the same manner as the first trial, the fish were divided into groups that had 0 , low, medium, and high antibody titers (Table 1). These fish were challenged by

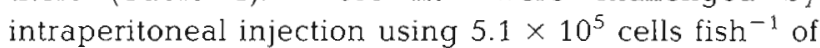
E. ictaluri rather than the higher challenge dose used in the first trial.

The mortalities in groups of fish with different antibody titers were compared statistically by the regression coefficient method described by Zar (1984).

Edwardsiella ictaluri ALG-88-122 was grown in 11 brain heart infusion broth on a stirring plate for $36 \mathrm{~h}$ at $25^{\circ} \mathrm{C}$. Cells were killed in $1 \%$ formalin and harvested by centrifugation at $600 \times g$ for $10 \mathrm{~min}$ at $4{ }^{\circ} \mathrm{C}$. The cells were washed 3 times in $4^{\circ} \mathrm{C}$ of $0.05 \mathrm{M}$ Tris buffer $(100 \mathrm{ml})$ that contained $1 \mathrm{mM}$ ethylenediaminetetraacetic acid (Tris-EDTA) at pH 7.8 using centrifugation $(1900 \times g$ for $10 \mathrm{~min})$. The cells were finally resuspended in $25 \mathrm{ml}$ of Tris-EDTA buffer and disrupted twice in a French press (Lugtenberg \& Van Alphen 1983 ) at $2500 \mathrm{~kg} \mathrm{~cm}^{-2}$. Intact cells and cell debris were removed by centrifugation $\left(1900 \times g, 4^{\circ} \mathrm{C}, 5 \mathrm{~min}\right)$. The supernatant was collected and designated as 'cell extract'. Protein concentration of the cell extract was determined by the method of Dulley \& Grieve (1975) and the extract was used to vaccinate channel catfish.

The antigen-impregnated feed was prepared by adding $20 \mathrm{ml}$ of cell extract, containing $2.0 \mathrm{mg}$ protein $\mathrm{ml}^{-1}$ to $100 \mathrm{~g}$ of commercial floating channel catfish feed, and thoroughly mixing immediately before use. Each of the 190 channel catfish (average size $39.0 \mathrm{~g}$ ) was immunized by intraperitoneal injection with $0.1 \mathrm{ml}$ of $5.0 \mathrm{mg}$ protein $\mathrm{ml}^{-1}$ of the cell extract from Edwardsiella ictaluri. Fish were divided into 3 groups of 90,50 , and 50 fish each and stocked into separate $1 \mathrm{~m}^{3}$ cages in a 0.8 ha pond. All fish were fed control feed daily at $2 \%$ of body weight. The group of 90 control fish which received the non-vaccine-feed was monitored weekly for $E$. ictaluri antibody. When the antibody titer in the control group had declined for 3 consecutive sampling periods, one test group was fed with antigen-impregnated feed every 5 th day while the second test group was fed the antigenimpregnated feed every 10th day. As with the controls, these teedings were at $2 \%$ of the body weight. Ten fish from each group were then sampled for antibody titers weekly after initiating feeding of the antigen-impregnated feed. The patterns of antibody titers were plotted and compared among the 3 groups.

\section{RESULTS}

When channel catfish with 0 , low, medium or high Edwardsiella ictaluri antibody titers were challenged with E. ictaluri, they demonstrated a strong relationship between degree of protection and the antibody titer. Regression coefficient (R) values were 0.95 and

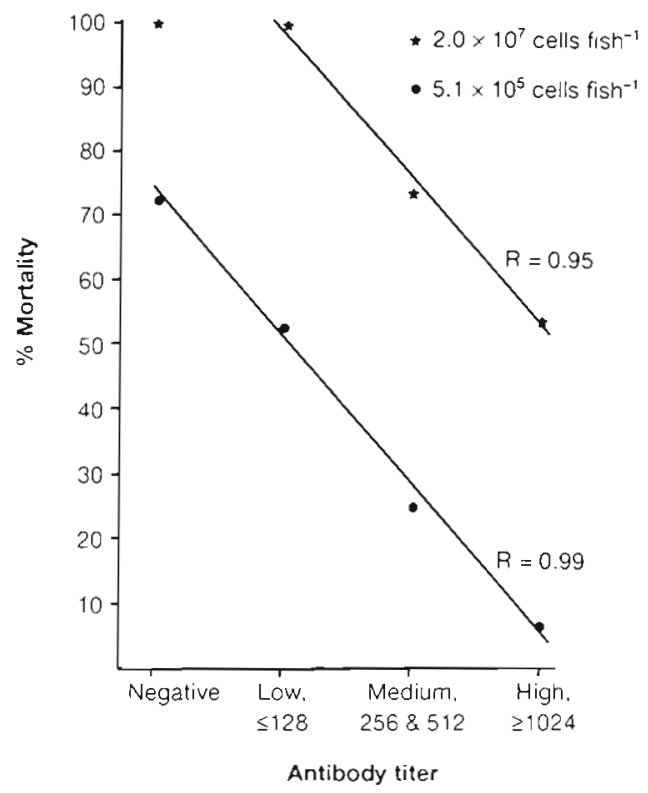

Fig. 1 Ictalurus punctatus. Relationship between the degree of protection and antibody titer in channel catfish that survived a natural Edwardsiella ictaluri infection. Fish in each antibody titer group were challenged by intraperitoneal injection with the E. ictaluri dose indicated 
0.99 in the first and second trials, respectively (Fig. 1). In challenge trials 1 and 2, groups of fish with no or low E. ictaluri antibody titers had the highest mortality ( $100 \%$ and $72.22 \%$, respectively) while fish in the high antibody titer groups had the lowest mortality $157.7 \%$ and $6.5 \%$, respectively). Mortalities of fish injected with $5.1 \times 10^{5}$ cells were lower than those of fish with corresponding antibody titers but injected with $2.0 \times 10^{7}$ E. ictaluri cells.

The antibody titer in the control group reached a peak at $18 \mathrm{~d}$ post vaccination and gradually declined. Feed impregnated with $E$. ictaluri cell extract was applied $39 \mathrm{~d}$ post intraperitoneal immunization with the cell extract (Fig. 2). The pattern of antibody titer was similar to the kinetics of the immune response of channel catfish to E. ictaluri (Vinitnantharat \& Plumb 1992). The antibody titer in the group fed every 10th day declined and then increased. However, in the group fed every 5th day, the antibody titer quickly stabilized and then increased.

\section{DISCUSSION}

Following successful chemotherapy of ESC, which brings mortality due to Edwardsiella ictaluri temporarily under control, there have been numerous reports of relapses into clinical disease. Relapse is particularly evident during long periods of mild weather during spring and fall when water temperatures remain in the critical 20 to $28^{\circ} \mathrm{C}$ range, the ideal temperature for ESC

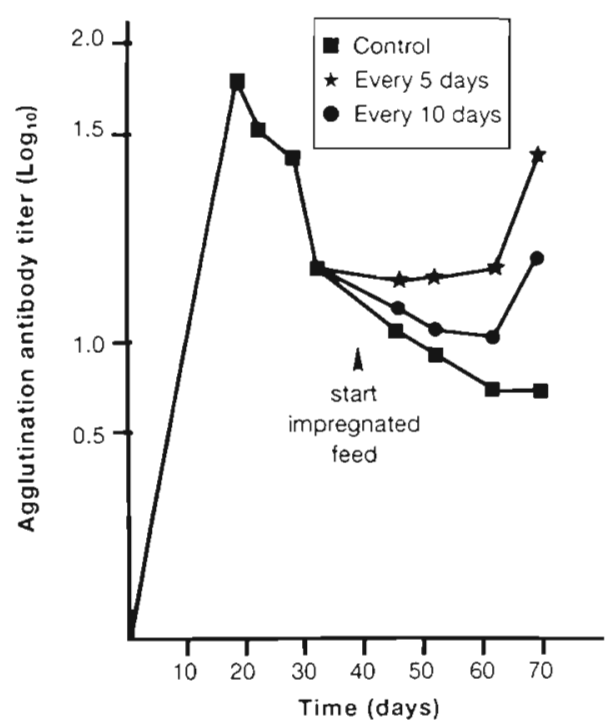

Fig. 2. Ictalurus punctatus. Agglutinating antibody titer in channel catfish vaccinated by injection with cell extract from Edwardsiella ictaluri and then fed antigen-impregnated feed every 5 th or 10 th day beginning $39 \mathrm{~d}$ after vaccinating by injection
(Plumb \& Schwedler 1982). It was shown in this study that the humoral antibody response of fish that survive an ESC epizootic varies from none (no antibody) to high (antibody titers greater than $1: 1024$ ). That fish with medium to high antibody titers are protected from reinfection suggests that it is the fish with lower titers that are vulnerable to $E$. ictaluri upon reexposure. The varying immune response of different fish probably explains the occurrence of relapses after an epizootic.

An injection challenge was chosen to ensure exposure of each fish to a known number of bacteria. Although it is an unnatural means of exposure, injection produces a more predictable mortality with a known number of Edwardsiella ictaluri than other methods of challenge.

It may not be appropriate to compare the 2 challenge experiments because they were carried out at different times, but fish in both trials were from the same population. In addition, in the experiments the similarity of the slopes of the 2 regressions relating mortality to antibody titer in the surviving fish from the naturally Edwardsiella ictaluri infected population (Fig. 1) is a good indication that the results were repeatable and that the timing of the experiments had little effect. In the high antibody titer fish, $57.7 \%$ died when chal-

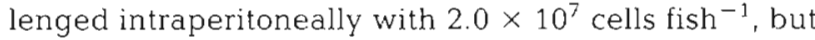
only $6.5 \%$ mortality occurred when the challenge dose was $5.1 \times 10^{5}$ cells fish ${ }^{-1}$. It can be concluded that the immunity of catfish can be overwhelmed if the number of E. ictaluri to which they are exposed is high enough. These data also indicate the need for using 2 or more concentrations of pathogens when testing for immunity, regardless of the method of infection.

Feeding antigen-impregnated feed at least every $5 \mathrm{~d}$ will maintain the antibody titer. However, the length of time and frequency that the antigen-impregnated feed should be applied need to be determined. The results in Fig. 2 were not analyzed statistically, because of the great variation in the antibody response of individual fish to the antigen. Indications are, however, that periodic restimulation of the immune response by feeding antigen (Edwardsiella ictaluri) to channel catfish would be helpful in maintaining a high antibody level in some of the fish in a given population and that it should provide increased protection for these fish against E. ictaluri. Present research is investigating the immunological efficacy of oral immunization.

\section{LITERATURE CITED}

Cossarini-Dunier, M. (1986). Protection against enteric redmouth disease in rainbow trout, Salmo gairdneri Richardson, after vaccination with Yersinia ruckeri bacterin. J. Fish Dis. 9: 27-33

Dulley, R. A., Grieve, P. A. (1975). A simple technique for 
eliminating interference by detergents in the Lowry method of protein determination. Analyt. Chem. 64: 136-141

Hawke, J. P., McWhorter, A. C., Steigerwalt, A. G., Brenner, D. J. (1981). Edwardsiella ictaluri sp. nov, the causative agent of enteric septicemia of catfish. Intern. J. syst. Bact. 31: $396-400$

Lugtenberg, B., Van Alphen, L. (1983). Molecular architecture and functioning of the outer membrane of Escherichia coll and other Gram-negative bacteria. Biochim. biophys. Acta 737: 51-115

Michel, C., Faivre, B. (1982). Occurrence and significance of agglutinating antibodies in experimental furunculosis of rainbow trout, Salmo gairdneri Richardson. J. Fish Dis. 5: $429-432$

Plumb, J A., Schwedler, T E. (1982). Enteric septicemia of catfish (ESC): a new bacterium problem surfaces. Aqua. Mag. 8(4): 26-27

Responsibie Subject Ecilior: T. Eveiyn, Nandimu, B.C., Canada
Plumb, J. A., Wise, M. L., Rogers, W. A. (1986). Modulary effects of temperature on antibody response and specific resistance to challenge of channel catfish, Ictalurus punctatus, immunized against Edwardsiella ictalur. Vet Immunol. Immunopathol. 12: 297-304

Saeed, M. O., Plumb, J. A. (1986). Immune response of channel catfish to lipopolysaccharide and whole cell Edwardsiella ictaluri vaccines. Dis. aquat. Org. 2: 21-25

Sandick, R. G., Rose, N. R. (1980). Agglutination reaction. In: Rose, N. B. Bigazzi, P. E. (eds.) Methods in immunodiagnosis, 2nd edn. John Wiley \& Sons, New York, p. 109-12?

Vinitnantharat, S., Plumb, J. A. (1992). Kinetics of the immune response of channel catfish to Edwardsiella ictaluri. J. aquat. Anim. Hith 4(3): 207-214

Zar, J. H. (1984). Biostatistical analysis, 2nd edn. PrenticeHall, Englewood Cliffs

Míanuscript first received. Jüy 21, 1332

Revised version accepted: October 8, 1992 